\title{
SEROLOGICAL MARKERS OF VIRAL, SYPHILITIC AND TOXOPLASMIC INFECTION IN CHILDREN AND TEENAGERS WITH NEPHROTIC SYNDROME: CASE SERIES FROM MATO GROSSO STATE, BRAZIL
}

\author{
Silvania França da Silva SOARES, Teresinha Lermen DONATTI \& Francisco José Dutra SOUTO
}

\begin{abstract}
SUMMARY
Some infections can be the cause of secondary nephrotic syndrome. The aim of this study was to describe the experience of a Renal Disease Reference Clinic from Central Brazil, in which serological markers of some infectious agents are systematically screened in children with nephrotic syndrome. Data were obtained from the assessment of medical files of all children under fifteen years of age, who matched nephrotic syndrome criteria. Subjects were tested for IgG and IgM antibodies against $T$. gondii and cytomegalovirus; antibodies against Herpes simplex, hepatitis C virus and HIV; and surface antigen (HBsAg) of hepatitis B virus. The VDRL test was also performed. 169 cases were studied. The median age on the first visit was 44 months and 103 (60.9\%) patients were male. AntiCMV IgG and IgM were found in $70.4 \%$ and $4.1 \%$, respectively. IgG and IgM against Toxoplasma gondii were present in $32.5 \%$ and $5.3 \%$, respectively. Two patients were positive for HBsAg, but none showed markers for HIV, hepatitis C, or Treponema pallidum. $\mathrm{IgG}$ and $\operatorname{IgM}$ against herpes simplex virus were performed on 54 patients, of which $48.1 \%$ and $22.2 \%$ were positive. IgM antibodies in some children with clinical signs of recent infection suggest that these diseases may play a role in the genesis of nephrotic syndrome.
\end{abstract}

KEYWORDS: Nephrotic syndrome; Kidney diseases/epidemiology; Infant; Mato Grosso State; Infectious diseases.

\section{INTRODUCTION}

Nephrotic syndrome can be provoked by primary or systemic kidney disease and is characterized by massive proteinuria, hypoalbuminaemia $(<2.5 \mathrm{~g} / \mathrm{dL})$, hyperlipidaemia, and lipiduria. In secondary nephrotic syndrome, the kidney is affected by changes induced by a systemic condition, such as infection, exposure to drugs, or cancer ${ }^{7,8}$. Nephrotic syndrome is like a chronic disease that increases the frequency of consultations in outpatient pediatric nephrology clinics, and that eventually prolongs hospitalization. This clinical condition usually extends to adolescence. Nephrotic syndrome in children, in most cases, is idiopathic, caused by minimal glomerular lesions (MGL), with good long-term prognosis. The two primary glomerular alterations during adolescence are MGL and focal segmental glomerulosclerosis (FSGS). Immunological phenomena are involved in the damage to the glomeruli, and therefore treatment of nephrotic syndrome is largely based on immunosuppression, particularly with corticosteroids ${ }^{1,8}$.

Chronic or prolonged infections by several agents, in particular hepatitis B and C, syphilis, toxoplasmosis, AIDS, and cytomegalovirus are some of the causes of secondary nephrotic syndrome s, $^{3,5,510,16,20,23,27,28}$. On the other hand, frequent use of immunosuppressants in children with kidney disease or kidney transplant recipients make these individuals susceptible to opportunistic infections by intracellular parasites such as cytomegalovirus (CMV) and herpes simplex virus (HSV) 1 or 2,14,21,22.

Most protocols for the management of children with nephrotic syndrome recommend screening of infectious agents, because these may require specific treatment ${ }^{1,15}$. Furthermore, immunosuppression in patients with chronic infections could lead to the worsening of the infection and of the general clinical condition.

Routine assessment of nephrotic syndrome causes was established in the Outpatient Clinic of Pediatric Nephrology, at Júlio Muller University Hospital (HUJM), Federal University of Mato Grosso, in the city of Cuiabá, in 1990, and includes serological tests to diagnose possible associated infectious diseases (toxoplasmosis, syphilis, hepatitis B and C, CMV, HIV). Serological tests to detect herpes simplex infection, was later introduced.

The aim of this study was to describe and analyze the accumulated experience with this routine assessment and its impact on the therapeutic approach and progression of affected patients.

\section{MATERIAL AND METHODS}

This is a descriptive study of a case series of nephrotic syndrome in children and adolescents monitored from 1990 to 2012 at the Outpatient 
SOARES, S.F.S.; DONATTI, T.L. \& SOUTO, F.J.D. - Serological markers of viral, syphilitic and toxoplasmic infection in children and teenagers with nephrotic syndrome: case series from Mato Grosso State, Brazil. Rev. Inst. Med. Trop. Sao Paulo, 56(6): 499-504, 2014

Clinic of Pediatric Nephrology, at Júlio Muller University Hospital, which serves as a reference clinic for the whole Mato Grosso State. Around 800 children and teenagers with renal and urinary tract diseases are monitored in this clinic. The medical records of all patients with criteria that confirmed the diagnosis of nephrotic syndrome and who underwent the research protocol for infectious diseases (hepatitis B and C, syphilis, AIDS, CMV, and toxoplasmosis) were reviewed. Since 2010, the evaluation of HSV 1 and 2 has been included in this protocol.

The protocol comprised the screening for IgG antibodies against $T$. gondii, CMV, and HSV; IgM antibodies against T. gondii, CMV, and HSV; antibodies against hepatitis $\mathrm{C}$ virus (HCV), and HIV; and screening for the surface antigen (HBsAg) of the hepatitis B virus (HBV), in addition to performing the Venereal Disease Research Laboratory (VDRL) test for treponemal infections. Immunological techniques have changed over time, and more recently, these have been performed by enzyme-linked immunosorbent assay (ELISA) and more modern derivatives thereof.

An electronic database was built with the aid of SPSS for Windows, version 11.0. Data were described as means or medians, proportions, and their dispersion and precision parameters. The review of medical records was approved by the clinical director of the hospital and its ethical aspects were reviewed and approved by the Ethics Review Board of the HUJM (Plataforma Brasil CAAE: 01897812.2.0000.5163), on June 13, 2012.

\section{RESULTS}

The study population consisted of 169 patients treated from January 1990 to August 2012, of which 103 (60.9\%) were male. The median age on the first visit was 44 months (interquartile range: $29-88$ months), and on the last visit, 118 months (interquartile range: 65-167 months). The median follow-up time was 43 months (interquartile range: 16-94 months).

All the patients were diagnosed with nephrotic syndrome, according to the criteria of the International Study of Kidney Disease in Children (ISKDC) $)^{11}$. Upon initial medical appointment, 72 (42.6\%) out of 169 presented hypertension and haematuria. It took one or more hospitalizations to control the edema in $86 \%$ of the patients. Only two patients did not receive corticosteroids.

Renal biopsy was performed on $82(48.5 \%)$ patients who had an unsatisfactory response to corticosteroids, patients aged less than one year, and patients with renal failure associated with nephrotic syndrome signs and symptoms, MGL (47.6\%) and FSGS (30.5\%), were more frequent.

Table 1 shows the results of serological tests for infections of interest. IgG antibodies against CMV (70.4\%) and against T. gondii (32.5\%) were identified as the predominant infectious agents. $\operatorname{IgM}$ antibodies against T. gondii and CMV were positive in 5\% and $4 \%$ patients, respectively. Two cases of hepatitis B were recorded. No cases of syphilis, HCV, or HIV infection were recorded. In terms of HSV, 54 (32\%) patients were assessed, and $\mathrm{IgG}$ and IgM antibodies were present in $48.1 \%$ and $22.2 \%$ of the cases, respectively.

Although a typical clinical condition of acute toxoplasmosis was not characterized, 18 patients received specific treatment against toxoplasmosis.
Table 1

Serological test results for toxoplasmosis, CMV, HIV, HBV, HCVC, syphilis, and HSV of 169 pediatric nephrotic patients in a hospital of Mato Grosso State, Central Brazil

\begin{tabular}{|c|c|c|c|}
\hline Infectious agent & $\mathrm{N}$ & Positive (\%) & Negative $(\%)$ \\
\hline T. gondii & 169 & & \\
\hline $\operatorname{IgG}$ & & $55(32.5)$ & $114(67.5)$ \\
\hline $\operatorname{IgM}$ & & $9(5.3)$ & $160(94.7)$ \\
\hline Cytomegalovirus & 169 & & \\
\hline $\operatorname{IgG}$ & & $119(70.4)$ & $50(29.6)$ \\
\hline $\operatorname{IgM}$ & & $7(4.1)$ & $162(95.9)$ \\
\hline Hepatitis B & 169 & & \\
\hline HBsAg & & $2(1.2)$ & $167(97.9)$ \\
\hline Hepatitis C & 169 & & \\
\hline Anti-HCV & & 0 & 169 \\
\hline HIV & 169 & & \\
\hline Anti-HIV & & 0 & 169 \\
\hline Syphilis & 169 & & \\
\hline VDRL & & 0 & 169 \\
\hline Herpes virus 1 and 2 & 54 & & \\
\hline $\operatorname{IgG}$ & & $26(48.1)$ & $28(51.9)$ \\
\hline $\operatorname{IgM}$ & & $12(22.2)$ & $42(77.8)$ \\
\hline
\end{tabular}

Nine of these patients showed positive $\operatorname{IgM}$ levels concomitant with early stage decompensated nephrotic syndrome. The other nine had elevated IgG levels compared to initial values, which was regarded as a possible reactivation of toxoplasmosis, as well as an unfavorable response to corticosteroids. Seven IgM-positive patients presented remission after treatment with sulfadiazine and pyrimethamine, but needed additional prednisone to achieve this remission. These patients relapsed, but retained their sensitivity to corticosteroids and showed favorable progression. Of the nine cases of suspected reactivation of toxoplasmosis that were treated, seven regained corticosensitivity (Table 2 ).

As noted for toxoplasmosis, no typical signs of acute infection were identified in the seven patients who tested positive for the antiCMV IgM test. In spite of it, the two patients who had the most severe nephrotic syndrome received ganciclovir. These patients presented initial clinical remission without the need for therapy using corticosteroids. Subsequently, both relapsed and were controlled with corticosteroids (Table 3). A patient with recent primary decompensated nephrotic syndrome and positive result in the CMV IgM test presented a spontaneous remission of nephrotic syndrome without the use of corticosteroids and showed no recurrence during eight years of follow-up.

Of the 12 patients positive for anti-HSV IgM, four received acyclovir, concomitant with corticosteroids, and showed good response. The other eight patients had already initiated corticotherapy and were under remission when the serology results were released. Five patients showed typical signs and symptoms of gingivostomatitis, concomitant with the 


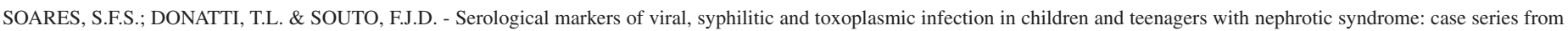
Mato Grosso State, Brazil. Rev. Inst. Med. Trop. Sao Paulo, 56(6): 499-504, 2014.

Table 2

Characteristics of nine patients with IgM antibodies against toxoplasmosis, including clinical progression, response to therapy, and type of renal injury

\begin{tabular}{|c|c|c|c|c|c|c|c|}
\hline Patient & Biopsy & $\begin{array}{c}\text { Clinical } \\
\text { presentation of } \\
\text { acute infection* }\end{array}$ & HTN & Hematuria & $\begin{array}{c}\text { Antiparasitic } \\
\text { treatment }\end{array}$ & $\begin{array}{l}\text { Response to } \\
\text { corticosteroids }\end{array}$ & Frequent relapses \\
\hline 1 & FSGS & - & + & - & + & + & + \\
\hline 2 & FSGS & + & - & - & + & + & + \\
\hline 3 & - & - & + & - & + & + & + \\
\hline 4 & FSGS & + & + & + & + & + & - \\
\hline 5 & MGL & + & + & + & + & - & + \\
\hline 6 & - & - & + & - & + & + & - \\
\hline 7 & - & - & + & + & + & + & - \\
\hline 8 & FSGS & - & + & + & + & - & + \\
\hline 9 & - & + & - & - & + & + & + \\
\hline
\end{tabular}

MGL = minimal glomerular lesions; FSGS = focal segmental glomerulosclerosis; HTN = Hypertension; Frequent relapses = two or more relapses of nephrotic syndrome in six months. *Clinical presentation of acute infection = fever and/or lymphadenopathy.

Table 3

Characteristics of seven patients with IgM antibodies against CMV, including clinical progression, response to therapy, and type of renal injury

\begin{tabular}{|c|c|c|c|c|c|c|c|}
\hline Patient & Biopsy & $\begin{array}{c}\text { Clinical } \\
\text { presentation of } \\
\text { acute infection* }\end{array}$ & HTN & Hematuria & $\begin{array}{l}\text { Treatment with } \\
\text { ganciclovir }\end{array}$ & $\begin{array}{l}\text { Response to } \\
\text { corticosteroids }\end{array}$ & Frequent relapses \\
\hline 1 & - & + & - & - & - & + & - \\
\hline 2 & - & - & - & - & - & + & - \\
\hline 3 & - & + & - & - & - & + & - \\
\hline 4 & - & + & - & - & + & + & + \\
\hline 5 & - & + & - & - & - & - & - \\
\hline 6 & MGL & + & - & - & - & + & + \\
\hline 7 & FSGS & + & + & + & + & - & + \\
\hline
\end{tabular}

MGL = minimal glomerular lesions; FSGS = focal segmental glomerulosclerosis; HTN = Hypertension. Frequent relapses = two or more relapses of nephrotic syndrome in six months. *Clinical presentation of acute infection = fever and/or lymphadenopathy.

initial phase of nephrotic syndrome. Three out of five had severe nephrotic syndrome with intense haematuria, which led to treatment with acyclovir and then with prednisone. One of them was considered corticoresistant (remission after using mycophenolate mofetil). The other two patients, who also had gingivostomatitis, showed good response to corticosteroids and, therefore, did not receive acyclovir (Table 4).

The two cases of hepatitis B occurred in the 1990s, in four- and seven-year-old girls, both $\mathrm{HBeAg-positive.} \mathrm{Both} \mathrm{children} \mathrm{received}$ corticosteroids, showed corticodependent behavior, but progressed to a resolution of the liver condition, with seroconversion to anti-HBs after six months of illness. In both cases, the renal disease remained active even after seroconversion.

\section{DISCUSSION}

The clinical management of patients with nephrotic syndrome, especially in pediatric patients, includes screening of potential secondary causes of nephrotic syndrome, such as infectious diseases. Screening is important because it enables the physician to address specific causative agents and because these patients are usually treated with immunosuppressants for the glomerular dysfunction ${ }^{11}$. This study discusses a case series consisting of 169 children and adolescents with nephrotic syndrome, with long-term follow-up. This nephrotic pediatric group represents the largest ever to be reported in Brazil.

IgG antibodies against CMV was the most prevalent marker of infectious disease $(70.4 \%)$, with toxoplasmosis as the second most common exposure $(32.5 \%)$. Similar statistics have been reported in previous studies involving general population from other Brazilian regions (32.4-74.5\% for toxoplasmosis and 80-90\% for cytomegalovirus) $)^{2,9,24,25}$. Both infections are known to be very common and may be asymptomatic or cause nonspecific febrile symptoms. Less frequently, they may involve the kidneys and even cause nephrotic syndrome ${ }^{4,17}$. The high frequency of 
SOARES, S.F.S.; DONATTI, T.L. \& SOUTO, F.J.D. - Serological markers of viral, syphilitic and toxoplasmic infection in children and teenagers with nephrotic syndrome: case series from Mato Grosso State, Brazil. Rev. Inst. Med. Trop. Sao Paulo, 56(6): 499-504, 2014

Table 4

Characteristics of the twelve patients with IgM antibodies against HSV 1 and 2, including clinical progression, response to therapy, and type of renal injury

\begin{tabular}{|c|c|c|c|c|c|c|c|}
\hline Patient & Biopsy & $\begin{array}{c}\text { Clinical } \\
\text { presentation of } \\
\text { acute infection* }\end{array}$ & HTN & Hematuria & $\begin{array}{c}\text { Treatment with } \\
\text { acyclovir }\end{array}$ & $\begin{array}{l}\text { Response to } \\
\text { corticosteroids }\end{array}$ & Frequent relapses \\
\hline 1 & MGL & + & - & + & + & - & - \\
\hline 2 & FSGS & - & + & - & - & + & + \\
\hline 3 & FSGS & - & + & + & - & - & + \\
\hline 4 & - & + & + & + & + & + & - \\
\hline 5 & GNM & - & + & + & - & + & - \\
\hline 6 & - & - & + & + & - & + & + \\
\hline 7 & - & + & + & + & + & + & - \\
\hline 8 & - & + & - & + & - & + & + \\
\hline 9 & - & + & - & - & - & + & + \\
\hline 10 & - & - & + & + & - & + & - \\
\hline 11 & FSGS & - & + & + & - & - & + \\
\hline 12 & FSGS & - & + & + & + & - & + \\
\hline
\end{tabular}

MGL = minimal glomerular lesions; FSGS = focal segmental glomerulosclerosis; GNM = membranous glomerulonephritis; HTN = Hypertension. $*$ Clinical presentation of acute infection $=$ gingivostomatitis and/or adenomegaly. Frequent relapses $=$ two or more relapses of nephrotic syndrome in six months.

prior exposure to these two agents, as observed in this study population, raises concern regarding their management because most nephrotic syndrome therapies use highly immunosuppressive drugs.

Serological indications of recently acquired infection (IgM-positive) by CMV or $T$. gondii occurred in $4 \%$ and $5 \%$ of patients, respectively. However, it was not possible to characterize febrile illness with lymphadenopathy or mononucleosis syndrome in many of these patients. This is in agreement with the previous report of TOPOROVSKI et al. on nephrotic syndrome cases that were seropositive for $T$. gondii ${ }^{27}$. Although an apparent initial response to specific treatment was observed in some cases, most patients later relapsed, making it difficult to interpret the actual role of these agents in the development of nephrotic syndrome. In parallel, the concomitant use of corticosteroids may have influenced the recovery of patients who received sulfamides, pyrimethamine, or ganciclovir. In cases involving reactivation of toxoplasmosis, there is also some speculation that the use of corticosteroids may have played a role in its aetiology. However, after specific anti-protozoan therapy, most patients again presented satisfactory response to corticosteroids. One hypothesis to explain this phenomenon would be that the control of the infectious disease facilitated the recovery of corticosensitivity. Anyway, the result of the screening for CMV and T. gondii infection markers in nephrotic syndrome cases emphasize the need for prospective studies that employ novel molecular biology techniques to better understand the precise role of these agents in the pathogenesis of nephrotic syndrome.

Two cases of hepatitis B were monitored in the 1990s. There was a significant decline in the incidence and circulation of this infection recently in Brazil due to the nationwide vaccination of children since $1998^{19}$. This may explain the low incidence of this infection as a cause of nephrotic syndrome in the present case series. HBV has been known for decades as the potential generator of nephrotic syndrome than the
CMV and $T$. gondii infection ${ }^{13,18,26}$. However, in these two cases, serologic cure of infection was documented during follow-up. Even so, the patients continued to experience relapses of nephrotic activity. This was an unexpected finding because nephrotic syndrome associated to HBV is always linked to intense viral replication, coupled with the accumulation of antigen-antibody complexes in the glomerular basement membrane ${ }^{18,26}$.

The behavior observed in hepatitis B cases raises the possibility that the infection may have triggered the development of glomerular disease in immunogenetically predisposed individuals. The same hypothesis could be applied to cases that test positive for CMV and T. gondii IgM antibodies.

Cases positive for IgM antibodies against herpes simplex presented typical clinical manifestations of this infection, more than for the other infectious agents investigated, such as gingivostomatitis, classic in cases of a primary herpetic infection. In one of the cases, the renal histology showed significant amounts of immunoglobulin deposits (full-house pattern), a very common characteristic of post-infectious glomerulonephritis.

Herpes simplex may have been the activating factor for the development of kidney disease, a phenomenon spurred by immunosuppression, or just a coincident event. Regardless of the role played by this agent, its cooccurrence with the recent-onset nephrotic syndrome suggests that the medical community should be alert in monitoring herpes infection in younger patients with nephrotic syndrome.

Other important infections also related to nephrotic syndrome, such as HIV, hepatitis $\mathrm{C}$ and syphilis were not found in this series. It may be possible that these diseases were not common in this particular age group. These agents may also have no epidemiological relevance to nephrotic 
SOARES, S.F.S.; DONATTI, T.L. \& SOUTO, F.J.D. - Serological markers of viral, syphilitic and toxoplasmic infection in children and teenagers with nephrotic syndrome: case series from Mato Grosso State, Brazil. Rev. Inst. Med. Trop. Sao Paulo, 56(6): 499-504, 2014.

syndrome and thus it may be impractical and more costly to perform routine screening for these agents.

The importance of monitoring the serological status of pediatric patients with kidney diseases, especially nephrotic syndrome, has been well established; the protocols of scientific associations have also presented guidelines on their assessment $t^{1,11,12,15}$. However, the influence of infectious diseases during the course of the disease has still proven to be a much broader subject to be explored.

It was highlighted the occurrence of cases of nephrotic syndrome with concomitant serologic pattern suggestive of acute or active infection by $T$. gondii, CMV, HBV, or herpes simplex. Certainly, more studies are needed to better understand the pathogenesis of nephrotic syndrome and the role of these infections in its progression.

\section{RESUMO}

\section{Marcadores sorológicos de infecções virais, sífilis e toxoplasmose em crianças e adolescentes com síndrome nefrótica: série de casos de Mato Grosso, Brasil}

Algumas infecções podem ser causa de síndrome nefrótica. $\mathrm{O}$ objetivo desse estudo foi descrever a experiência de clínica pediátrica de doenças renais do Brasil Central, onde marcadores sorológicos de algumas doenças infecciosas são sistematicamente avaliados em crianças com síndrome nefrótica. Dados foram obtidos de registros médicos de todas as crianças com menos de 15 anos que preenchiam critérios de síndrome nefrótica. Os participantes foram testados para presença de IgG e IgM contra Toxoplasma gondii e citomegalovirus; anticorpos contra herpes simples, vírus da hepatite C e HIV, além do antígeno de superfície da hepatite B (HBsAg). VDRL também foi testado. 169 casos foram estudados. A idade média na primeira visita foi 44 meses e 103 eram do sexo masculino (60.9\%). Anti-CMV IgG e IgM foram identificados em $70,4 \%$ e $4,1 \%$, respectivamente. IgG e $\operatorname{IgM}$ contra $T$. gondii eram positivos em $32,5 \%$ e 5,3\%. Dois pacientes eram HBsAg positivos, mas nenhum mostrou positividade para HIV, hepatite $\mathrm{C}$ ou sífilis. IgG e IgM contra herpes simples foram realizados em 54 pacientes, dos quais $48,1 \%$ e $22,2 \%$ eram positivos. Anticorpos IgM positivos em algumas crianças com sinais clínicos de infecção recente sugerem que essas doenças podem exercer um papel na gênese da síndrome nefrótica.

\section{REFERENCES}

1. Abrantes MM, Cardoso LSB, Lima EM, Silva JMP, Diniz JS, Bambirra EA, et al Clinical course of 110 children and adolescents with primary focal segmental glomerulosclerosis. Pediatr Nephrol. 2006;21:482-9.

2. Almeida LN, Azevedo RS, Amaku M, Massad E. Cytomegalovirus seroepidemiology in an urban community of São Paulo, Brazil. Rev Saude Publica. 2001;35:124-9.

3. Beale MG, Strayer DS, Kissane JM, Robson AM. Congenital glomerulosclerosis and nephrotic syndrome in two infants. Speculations and pathogenesis. Am J Dis Child. $1979 ; 133: 842-5$

4. Besbas N, Bayrakci US, Kale G, Cengiz AB, Akcoren Z, Akinci D, et al. Cytomegalovirusrelated congenital nephrotic syndrome with diffuse mesangial sclerosis. Pediatr Nephrol. 2006;21:740-2.
5. Chen YM, Marcos LA, Liapis H, Steinberg TH, Morrison AR. An unusual cause of membranous glomerulonephritis in a patient with HIV. Int Urol Nephrol. 2012;44:9836.

6. Comoli P, Ginevri F. Monitoring and managing viral infections in pediatric renal transplant recipients. Pediatr Nephrol. 2012;27:705-17.

7. Crew RJ, Radhakrishnan J, Appel G. Complications of the nephrotic syndrome and their treatment. Clin Nephrol. 2004;62:245-59.

8. Eddy AA, Symons JM. Nephrotic syndrome in childhood. Lancet. 2003;362:629-39.

9. Francisco FM, Souza SLP, Gennari SM, Pinheiro SR, Muradian V, Soares RM. Seroprevalence of toxoplasmosis in a low-income community in the São Paulo municipality, SP, Brazil. Rev Inst Med Trop Sao Paulo. 2006;48:167-70.

10. Gilbert RD, Wiggelinkhuizen J. The clinical course of hepatitis B virus associatednephropathy. Pediatr Nephrol, 1994;8:11-4.

11. International Study of Kidney Disease in Children. Nephrotic syndrome in children: prediction of histopathology from clinical and laboratory characteristics at time of diagnosis. A report of the International Study of Kidney Disease in Children. Kidney Int. 1978;13:159-65.

12. International Study of Kidney Disease in Children. The primary nephrotic syndrome in children. Identification of patients with minimal change nephrotic syndrome from initial response to prednisone. A report of the International Study of Kidney Disease in Children. J Pediatr. 1981;98:561-4.

13. Johnson RJ, Couser WG. Hepatitis B infection and renal disease: clinical, immunopathogenetic and therapeutic considerations. Kidney Int. 1990;37:663-76.

14. Kidney Disease Improving Global Outcomes (KDIGO) Glomerulonephritis Work Group. KDIGO Clinical Practice Guideline for glomerulonephritis. Kidney Int Suppl. 2012;2(2):139-274. Available from: http://www.kidney-international.org

15. Kranz B, Vester U, Wingen AM, Nadalin S, Paul A, Broelsch CE, et al. Acute rejection episodes in pediatric renal transplant recipients with cytomegalovirus infection. Pediatr Transplant. 2008;12:474-8.

16. Langhammer J, Birk HW, Zahner H. Renal disease in lymphatic filariasis: evidence for tubular and glomerular disorders at various stages of the infection. Trop Med Int Health. 1997;2:875-84

17. Numata A, Akimoto T, Toshima M, Iwazu Y, Otani N, Miki T, et al. Membranous nephropathy in an HIV-positive patient complicated with hepatitis B virus infection. Clin Exp Nephrol. 2011;15:769-73.

18. Ozdamar SO, Gucer S, Tinaztepe K. Hepatitis B virus associated nephropathies: a clinicopathological study in 14 children. Pediatr Nephrol. 2003;18:23-8.

19. Pereira LM, Martelli CM, Merchán-Hamann E, Montarroyos UR, Braga MC, de Lima ML, et al. Population-based multicentric survey of hepatitis B infection and risk factor differences among three regions in Brazil. Am J Trop Med Hyg. 2009;81:240-7.

20. Poyrazoglu HM, Dursun I, Bastug F, Gunduz Z, Akyıldız BN, Tulpar S. Cytomegalovirus infection and haemophagocytosis in a patient with congenital nephrotic syndrome. Pediatr Nephrol. 2009;24:2257-9.

21. Rizza V, Coletti G, Grimaldi A, Clemente K, Cocco P, D'Angelo M, et al. A rare case of herpes simplex type 1 bronchopneumonia associated with cardiomegaly in renal transplantation. Transplant Proc. 2011;43:1210-2

22. Rubin RH. The pathogenesis and clinical management of cytomegalovirus infection in the organ transplant recipient: the end of the 'silo hypothesis'. Curr Opin Infect Dis. 2007;20:399-407. 
SOARES, S.F.S.; DONATTI, T.L. \& SOUTO, F.J.D. - Serological markers of viral, syphilitic and toxoplasmic infection in children and teenagers with nephrotic syndrome: case series from Mato Grosso State, Brazil. Rev. Inst. Med. Trop. Sao Paulo, 56(6): 499-504, 2014.

23. Sandhu G, Stokes MB, Meisels I. Delayed spontaneous resolution of nephrotic syndrome in a patient with hepatitis $\mathrm{C}$ virus-associated membranoproliferative glomerulonephritis. NDT Plus. 2010;3:363-5.

24. Souza CO, Tashima NT, Silva MA, Tumitan AR. Estudo transversal de toxoplasmose em alunas de um curso superior da região de Presidente Prudente, Estado de São Paulo. Rev Soc Bras Med Trop. 2010;43:59-61.

25. Suassuna JH, Leite LL, Villela LH. Prevalence of cytomegalovirus infection in different patient groups of an urban university in Brazil. Rev Soc Bras Med Trop. 1995;28:1058 .
26. Takekoshi Y, Tochimaru H, Nagata Y, Itami N. Immunopathogenetic mechanisms of hepatitis B vírus-related glomerulopathy. Kidney Int Suppl. 1991;35:S34-9.

27. Toporovski J, Romano S, Hartmann S, Benini W, Chieffi PP. Nephrotic syndrome associated with toxoplasmosis: report of seven cases. Rev Inst Med Trop Sao Paulo. 2012;54:61-4

28. Vachvanishsanong P, Mitarnum W, Tungsinmunkong K, Dissaneewate P. Congenital and infantile nephrotic syndrome in Thai infants. Clin Pediatr (Phila). 2005;44:169-74.

Received: 10 February 2014

Accepted: 25 March 2014 